doi: 10.14267/cojourn.2019v4n2a2

\title{
The Legacy of Versailles in International Relations Theory
}

\author{
Kinga Szálkai ${ }^{1}$ \\ "The main lesson (...) of the (...) Conference is that it is essential that the main Powers \\ should be clear from the start exactly where realism ends and idealism begins."
}

(Harold Nicolson, 1942)

\begin{abstract}
The legacy of Versailles is a rather well-defined and thoroughly researched area in the discipline of History. But what did the Treaty of Versailles and the events surrounding the peace conference give to the discipline of International Relations? In order to answer this question, the article first examines the place of Versailles in the foundational myths of the discipline. After that, in the second part, it briefly reviews the most persistent and influential ideas in IR which have emerged during the construction of the new world order of the time, putting a special emphasis on the concept of national self-determination as the "new master principle" of the international society after Versailles.
\end{abstract}

Keywords: Versailles, IR, theory, foundational myth, liberal internationalism, national self-determination

\section{Introduction}

As the $100^{\text {th }}$ anniversary of the Versailles Peace Treaty is passing by, circles of historians fondly commemorate the well-known and much recited events of the peace conference, their background and their far-reaching consequences. The debates and controversies within the historiography of Versailles have been present since the very days of the negotiations; the books and studies written on the various historical perspectives, contradictions and standpoints have filled several libraries during the past one-hundred years (for the historiography of Versailles, see the article by Baranyi Tamás in this issue of COJOURN). The legacy of Versailles is a rather well-defined and thoroughly

\footnotetext{
${ }^{1}$ Kinga Szálkai is an assistant professor at the Department of International Relations and European Studies at Eötvös Loránd University.
} 
doi: 10.14267/cojourn.2019v4n2a2

researched area in the discipline of History. But what did the Treaty of Versailles and the events surrounding the peace conference give to the discipline of International Relations?

If we take a closer look at IR and its perspectives on Versailles ${ }^{2}$, we encounter statements that may be surprising upon first glance. For example, Anievas claims that "the theoretical significance of Versailles for IR can hardly be overstated" (Anievas, 2014: 619), but then, in the same article, he goes on to insert a footnote referring to Randall Schweller's (2001) observation that "there are surprisingly few substantive studies within IR specifically examining the making of peace settlements and particularly Versailles" (Anievas, 2014: 643).

In fact, both statements are true. On the one hand, according to its most widespread foundational myth, even the birth of IR as a discipline is inseparable from Versailles and the surrounding controversies culminating in the signature of the peace treaty in 1919. Although the development of the discipline was undoubtedly a longer process, several new principles and approaches were articulated during the negotiations concerning the new world order after WWI, which have defined IR since then. On the other hand, the notion of Versailles and the direct references to the related events as formative sources of IR theory are mentioned in detail only on a few occasions, especially in the form of inserting IR-related elements in studies about the history of the peace conference and its aftermath (e.g. Boemeke et al, 1998; Smith, 2018), and not vice versa. In spite of its assumed significance, neither IR textbooks (e.g. Steans et al. 2010; Smith et al., 2016; Baylis et al., 2016; Jackson et al., 2018), nor canonized classical readings of IR theory (e.g. Carr, 1946 [1939]; Morgenthau, 1948) refer to the treaty, the peace conference and the consequences in detail; they only reference these subjects in sweeping generalisations, and treat them as self-explanatory.

The aim of this article is to shed more light on the relationship between Versailles and the foundations of IR theory, reviewing the place and importance of the negotiations to the discipline. In order to do so, the article first examines the place of Versailles in the foundational myths of the discipline. After that, in the second part, it briefly reviews the most persistent and influential ideas in IR which have emerged during the construction of the new world order of the time, putting a special emphasis on the concept of national

\footnotetext{
${ }^{2}$ In this article, the notion 'Versailles' does not only refer to the Treaty of Versailles concluded with the German Reich, or the Paris Peace Conference. 'Versailles' here comprises all negotiations and controversies which surrounded the creation of the new world order which emerged in the last years and in the aftermath of WWI.
} 
doi: 10.14267/cojourn.2019v4n2a2

self-determination as the "new master principle" of the international society after Versailles (Osiander, 1994: 255).

\section{The $100^{\text {th }}$ Anniversary of the Birth of a Discipline: The Place of Versailles in the Foundation of IR}

\section{The Twin Towers ${ }^{3}$ of Versailles and Aberystwyth}

In 2019, scholars of IR commemorate not only the centenary of the Treaty of Versailles. The $100^{\text {th }}$ anniversary of the foundation of the first university institution in International Relations (the Woodrow Wilson Chair of International Politics at the University College of Wales), in Aberystwyth in 1919, is another memorable event, which draws attention to the often-emphasized fact that the closing of WWI, the Paris peace negotiations, and the surrounding controversies were decisive elements in the establishment of IR as a discipline, and directly led to the necessity of its institutionalisation in the academic sphere. However, it is not possible to commemorate this symbolic turning point without considering the extensive works of revisionist historians and IR theorists, who have recently clarified the arbitrariness of presenting this period as the birth year (or, as its critiques write, the 'overnight' birth [de Carvalho et al., 2011: 737]) of the discipline.

According to its most widespread foundational myth, the need for the discipline of IR was created by the desire to eliminate and prevent wars, and directly stemmed from the devastating events and consequences of WWI. In this period of time - so the myth goes -, scholars had first turned their gaze to the international as an autonomous domain of theoretisation on its own right (de Carvalho et al., 2011: 736). In 1939, even Carr argued that before 1914, "nowhere, whether in universities or in wider intellectual circles, was there organised study of current international affairs" (Carr, 1946 [1939]: 1). In this sense, the establishment of the first IR chair in Aberystwyth could not have been imagined without the peace negotiations in Versailles, and the former was a logical consequence of the latter - both reinforcing the foundational myth of IR.

Carr's statement is, however, not true. With the strengthening interest in the history of the discipline after the end of the Cold War and the emergence of numerous critiques of its mainstream schools, the roots of IR have also become revisited. Research underlined that during the last decades of the $19^{\text {th }}$ century, debates about classical IR-

\footnotetext{
${ }^{3}$ The original expression "the twin towns of Versailles and Aberystwyth" was coined by de Carvalho et al. (2011: 749).
} 
doi: 10.14267/cojourn.2019v4n2a2

related issues, such as great power politics, imperialism, geopolitics and trade evolved, while in 1880, the first Political Science Department in the US was established at Columbia University, dealing with the systematic study of international politics, among others (de Carvalho et al., 2011: 748). According to Schmidt, the first book that could be qualified as IR was published two decades before the alleged birth of the discipline, in 1900, by Paul Reinsch, with the title World Politics at the End of the Nineteenth Century (Schmidt, 1998: 70). Vitalis mentions that related to the expanding colonial administrations of the great powers, several new courses were opened at universities which dealt with international relations. Publications on related topics were also encouraged (Vitalis, 2005: 166), such as the predecessor of the prestigious IR journal Foreign Affairs, which was established in 1910 under the name of the Journal of Race Development (de Carvalho et al., 2011: 748). In 1925, allegedly just five years after the official birth year of the discipline, a textbook with the title International Relations (written by Buell) and a collection titled Syllabus on International Relations (written by Moon) were published, accumulating knowledge created during the previous decades concerning war, imperialism, militaries and armaments in the international sphere (Vitalis, 2005: 166), proving that IR was not in fact born 'overnight' in 1919.

\section{In the Rearview of Realists: Great Debates, Great Narratives}

Versailles and the surrounding controversies are also assumed to have created a turning point that initiated the so-called 'First Great Debate' between Idealism and Realism in the 1920s-1930s. According to the mainstream historical narrative of IR (see Quirk and Vigneswaran, 2005: 99-103), this was the beginning of a line of debates which have been forming the main views and assumptions of the emerging schools of the discipline until today. This narrative on the 'Great Debates', as revisionist historians and IR theorists have also proved, is no less fictional than that of the birth of the discipline in $1919-$ however, it undeniably represents the nature of the development of IR in a concise form.

The history of IR was rather under-emphasized even as late as in the 1970s-1980s, and discussions about the development of the discipline only went back to the time of WWII (Donnelly, 1995: 181). The narrative on the 'Great Debates' referring to 1919 as the starting point of the 'Idealist-Realist' divide was established as an outcome of the dominant position of Realism in IR during the Cold War years, especially after WWII and in the 1950s-1960s. IR scholars often treat history as a multitude of events on which theories can be applied, and in their attempts to do so, they frequently ignore where those 
doi: 10.14267/cojourn.2019v4n2a2

events are rooted historically (Ashworth, 2002: 33). It was not otherwise in the case of Versailles and the surrounding controversies. In the analysis of these, Realists of the Cold War narrowed their focus to an extreme extent to be able to discredit Liberalism and vindicate their own theories, so as to strengthen their own dominant position within the discipline. In the meantime, they tended to oversimplify and understate the significance of many details of the events of the period, as it fit their narrative. The Realist narrative of the 'First Great Debate' thus emphasizes the victory of Carr, Morgenthau and Niebuhr over the allegedly rather naïve but benevolent, 'legalistic-moralistic' idealists of Wilson, Angell and Zimmern, who supported ideas that served as the main foundations of liberal internationalism in the $20^{\text {th }}$ century. This narrative argues not only that Realism won the 'First Great Debate' by offering a more accurate and practically more applicable worldview than Liberalism, but also emphasizes that the failure of 'Idealism' in both theory and practice was the reason which led the world to the bloodshed of WWII. The resulting myth discredited liberal internationalism for a long time.

The historical narratives of IR, however, are subjects to constant change. Liberals were thus, eventually, able to rehabilitate their "predecessors" in the 1920s and 1930s. Other lessons were drawn regarding the fictionality of the narrative of the 'Great Debates'. As Liberalism had established and strengthened itself as a mainstream school of IR in the 1970s-1980s, the understanding and the label of the 'Idealist' side in the 'First Great Debate' also began to shift. "Idealist liberalism”, "liberal idealism”, “classical liberalism" are all expressions that are in use to refer to the loosely defined group of ideas emerging in the context of Versailles and the surrounding controversies. Several of these ideas were later used as the foundations on which the Liberal school of IR could develop. The changing labels signify the attempts of followers of Liberalism to (similarly to the earlier efforts of Realists) extrapolate Liberalism's presence to the time of the alleged birth of the discipline, thus giving it more legitimacy and weight by "virtue" of stemming from the era of Versailles.

\section{Beyond Foundational Myths}

Overall, as revisionist historians and IR theorists have proven, the myth of the birth of IR in 1919 is a product of "an ahistorical extrapolation backwards of current developments and concerns in international relations" (de Carvalho et al., 2011: 737); there were no defining 'Great Debates' taking place in the strict sense of the tern. Rather, there developed multiple parallel discourses on several diverging issues. If there is a period to 
doi: 10.14267/cojourn.2019v4n2a2

be named as the time of the birth of the discipline, the years following WWII would be much more suitable for this aim (Schmidt, 1998; Guilhot, 2008). However, the legacy of Versailles and the surrounding controversies still appear as the cornerstone and the starting point of the discipline. The symbolic meaning of 1919 has been built into the mainstream historical narratives, and - with the necessary source criticism - continues to serve as a useful tool to illustrate the nature, the main agenda and the diverging assumptions of IR for beginners as well as the broader interested public. Students of IR encounter the notion of the 'First Great Debate' almost without exception. They are also acquainted, typically, with Wilsonian Idealism, the League of Nations and national selfdetermination in the first months of their studies - which are then repeatedly referenced, again and again, in the course of their becoming scholars of IR, regardless of which school of IR their respective university institute leans toward. The legacy of Versailles and its aftermath is, thus, inherently built into the history and historiography of the discipline of IR and remains part of the standard introductory process of anyone who intends to enter this field of study.

\section{The Legacy of Versailles-Related Controversies: Principles and Critiques}

\section{New Diplomacy for a New World Order?}

Although the discipline of IR did not begin with a 'Big Bang' (de Carvalho et al., 2011: 738 ) in 1919, Versailles and the surrounding controversies had created an environment which encouraged and facilitated its development. Wilson and his followers embarked upon the road to redesign the architecture of the international system in the spirit of an early liberal internationalism, which led to the emergence of several new principles and approaches in the field of IR, and strengthened the significance and position of some earlier considerations. In the followings, the article reviews the most persistent and influential ideas in IR which have emerged as a consequence of Versailles.

One of the most tangible theoretical principles that have appeared during the negotiations was open diplomacy. ${ }^{4}$ As Carr writes in 1939, “down to 1914, the conduct of international relations was the concern of persons professionally engaged in it" (Carr, 1946 [1939]: 1). Foreign offices worked independently of party politics or public opinions, while international relations, including warfare, was almost exclusively the

\footnotetext{
${ }^{4}$ The principle of open diplomacy, however, was never applied consciously in practice during the Paris peace negotiations (see Keylor, 1998: 481-486).
} 
doi: 10.14267/cojourn.2019v4n2a2

business of high-ranking soldiers and diplomats. The events of WWI contributed to the rise of a discourse on a 'new diplomacy', the primary objective of which was to make international relations more transparent, emphasizing the problems with secret treaties and the lack of public involvement in decision-making about international relations (Keylor, 1998; Weisbrode 2014).

The new approach towards diplomacy and international relations, however, went beyond the mere transparency of international relations, and culminated in the creation of a whole dictionary of new principles for a new world order. The spirit of the time is illustrated well by the ideas of the British Union of Democratic Control (UDC) about the rules of a new way of conducting international affairs as early as 1914, in the following four points: 1) the population's consent is necessary for a transfer of territory; 2) the parliament has to be involved in decisions about international treaties; 3) Britain has to refrain from alliances that function on the mechanism of the balance of power and use the means of an international court for the settlement of its disputes; 4) arms reduction. In 1916, a fifth point was added: the promotion of free trade and the termination of trade wars (Knock, 1995: 37). The proposed guidelines of postwar settlement by Wilson ${ }^{5}$ developed these ideas further. The building blocks of the new world order became canonized in the form of his Fourteen Points (1918), and later appeared in the Treaty of Versailles (1919) and in the Covenant of the League of Nations (1919). These documents articulated the main principles for the reconstruction of the world order, highlighting the concepts of open diplomacy, democracy, freedom of the seas, freedom of trade, arms reduction, national self-determination, equality of nations, territorial integrity, the peaceful settlement of disputes, international cooperation, and collective security. In this form, Versailles and the surrounding controversies did not only lay and strengthen the foundations of a new world order, but also those of liberal internationalism and Liberalism as a school in IR theory.

For the keen eye, the spirit of Versailles and the surrounding controversies may also have some features that resemble an early version of an international society, although the notion was coined by Bull only in 1977, defined as

\footnotetext{
${ }^{5}$ It was, obviously, not Woodrow Wilson who invented the central principles of liberal internationalism. The mentioned principles have a rather long history in the development of liberal thought, and they had their proponents in Wilson's era as well. However, in the great narratives of history and IR, and in the imagination of the peoples of the world, early liberal internationalism ('Idealism') became intertwined with Wilson's charismatic (for a while, even messianistic) person in the time of Versailles and the surrounding controversies (Manela 2007b: 125).
} 
doi: 10.14267/cojourn.2019v4n2a2

"a group of states, conscious of certain common interests and common values, form a society in the sense that they conceive themselves to be bound by a common set of rules in their relations with one another, and share in the working of common institutions. (...) recognising certain common interests and perhaps some common values, they regard themselves as bound by certain rules in their dealings with one another (...). At the same time they cooperate in the working of institutions such as the forms of procedures of international law, the machinery of diplomacy and general international organisation, and the customs and conventions of war" (Bull, 1995 [1977]: 13).

In the case of the new world order established in Versailles, common interests and common values were articulated in the form of the above-mentioned principles, and the basis of international cooperation was created to settle questions of international law, diplomacy, international institutions and war. Democracy was a very significant building block for this early model of international society, and 'the principle of public right' was often emphasized in Wilson's formative speeches (Holsti 1998 [1991]: 177), establishing common value-based grounds for mutual understanding at the international level.

The existence of this early international society is thoroughly intertwined with the principle of collective security. Wilson and his followers argued that the main cause of WWI was the instability enhanced by the traditional balance-of-power politics of the great powers. Therefore, in the new world order, they put emphasis on the principle of collective security to replace the balance-of-power mechanism (Knock 1998: 114), conceptualized in the Covenant of the League of Nations in the following way:

"(Article 10) The Members of the League undertake to respect and preserve as against external aggression the territorial integrity and existing political independence of all Members of the League. In case of any such aggression or in case of any threat or danger of such aggression the Council shall advise upon the means by which this obligation shall be fulfilled.

(Article 11) Any war or threat of war, whether immediately affecting any of the Members of the League or not, is hereby declared a matter of concern to the whole League, and the League shall take any action that may be deemed wise and effectual to safeguard the peace of nations." 
doi: 10.14267/cojourn.2019v4n2a2

The key international institution to hold this new international society together and implement its common values and interests was the League of Nations. Although its establishment was surrounded by rather abstract, at times even pathetic, declarations about the role of the organization (Wilson compared the League to a "searching light of conscience" ${ }^{6}$ ), it had very tangible and significant benefits both for the Liberal school of IR in general, and concerning the theory of international organisations in particular. On the one hand, its Covenant contributed to the canonization of the principles of liberal internationalism and the broader approach of Liberalism towards the conduct of international affairs, institutionalizing international cooperation in several fields, such as economy, society, science, technology, and culture (Fleury, 1998: 509). On the other hand, even if the League was indeed very far from being perfectly constructed, it has served the theory of international organisations as a case study for analysis and a model to improve, while several existing international organizations proudly trace their roots back to the structure and the values upon which the League was established (Goodrich, 1947; Davies, 2012).

Overall, even though some critical accounts accuse the League of discrediting international organisations due to its very obvious flaws and failures in practice (Fleury, 1998: 518), the founding principles of the organization survived its existence, and keep influencing the development of the United Nations and other international organisations in general. As for the new world order constructed by 'Wilsonian Idealists', as the above discussion has shown, it provided much more for IR than Realists may have assumed: a set of ephemeral principles, a failed attempt at their practical implementation, and an organization responsible for much of this failure. In the direct aftermath of Versailles, the great powers "accepted Wilsonianism as the foundational discourse for a redesigned international system" (Smith, 2018: 264), and its reflections in IR theory (both on the grand and middle levels) has continued to influence the development of the discipline, providing a firm basis for the debates around the following new international orders emerging from WWII and the Cold War.

\footnotetext{
6 "My conception of the League of Nations is just this, that it shall operate as the organized moral force of men throughout the world and that whenever or wherever wrong and aggression are planned or contemplated, this searching light of conscience will be turned upon them and men everywhere will ask, "What are the purposes that you hold in your heart against the fortunes of the world?" (Wilson, 1927: 330).
} 
doi: 10.14267/cojourn.2019v4n2a2

Wilsonian Nationalism? The Controversial Principle of National Self-Determination in Europe

The new international order was built on nation-states, which brought about one of the most heated controversies of the Versailles and interwar era: the issue of national selfdetermination. In 1918, Wilson, the most ardent proponent of the concept at the time, stated that

"This war had its roots in the disregard of the rights of small nations and of nationalities which lacked the union and the force to make good their claim to determine their own allegiances and their own forms of political life. (...) National aspirations must be respected; peoples may now be dominated and governed only by their own consent. 'Self-Determination' is not a mere phrase. It is an imperative principle of action, which statesmen will henceforth ignore at their peril" (Wilson, 1927: 180).

As for the Fourteen Points, the Treaty of Versailles and the Covenant of the League of Nations, national self-determination was not directly mentioned therein, ${ }^{7}$ however, its spirit was visible in the territorial decisions redrawing the borders of Europe, and thus, with Osiander's words, it had become the "new master principle" of the international society after Versailles (Osiander, 1994: 255).

The content of the principle, however, was rather vague. The origins of its articulation in the peace negotiatons can be traced back to three substantive and interrelated principles appearing in Wilson's speeches: the principle of public right, government by consent of the governed, and democracy. On the basis of these, he could declare "that nobody has the right to impose sovereignty upon anybody else; that, in disposing of the affairs of a nation, that nation or people must be its own master and make its own choice" (Wilson, 1919a). The most widely accepted core of the practical application of the principle of national self-determinism, the so-called 'Wilsonian nationalism', was "to make state frontiers coincide with the frontiers of nationality and language" (Hobsbawm, 1992 [1990]: 132-133), which has also often been interpreted as being grounded in concepts of political or territorial independence and ethnicity.

In practice, however, it proved largely impossible to make borders and nationalities coincide in Europe after WWI (see Hobsbawm, 1992 [1990]: 131-162).

\footnotetext{
${ }^{7}$ Except for two rather indefinite indications of the concept in Points V and VI, referring to colonies' and Russia's right to determine their own development.
} 
doi: 10.14267/cojourn.2019v4n2a2

Moreover, the discussion of the practical application of the idea of national selfdetermination in Europe was often based on a lack of knowledge or insufficient information (see Lynch, 2002). In this sense, the principle of self-determination did not only trigger overly great expectations in Central Europe and foster the spread of nationalism, but also planted the seeds of injustice in several parts of the continent (Lynch, 2002). Although Wilson was committed to the implementation of the principle "without introducing new or perpetuating old elements of discord and antagonism that would be likely in time to break the peace of Europe and consequently of the world" (Wilson, 1918), the "new master principle" of the new world order significantly contributed to the demise of the Versailles system, generating processes that were in sharp contradiction with the other principles of liberal internationalism.

Considered as an essential principle of international law (ius cogens) today, the concept first appeared in Article 1 of the Charter of the United Nations (1945), and was codified in Article 1 of the International Covenant on Civil and Political Rights (1966), stating that "all peoples have the right of self-determination. By virtue of that right they freely determine their political status and freely pursue their economic, social and cultural development." The principle of national self-determination, supported and spread by Wilson and his followers in Versailles, was built on the approaches of liberal internationalism and the Liberal school of IR. However, the general vagueness of the concept continues to make its practical application in addressing political aspirations of independence controversial, up to this day.

\section{Wilsonian Nationalism? National Self-Determination on Tour around the Colonies}

In 1919, the principle of national self-determination resonated not only in Europe, but attracted the attention of colonized peoples and their leaders supporting anti-colonial nationalism all over the world. The fifth of the Fourteen Points called for

"a free, open-minded, and absolutely impartial adjustment of all colonial claims, based upon a strict observance of the principle that in determining all such questions of sovereignty the interests of the populations concerned must have equal weight with the equitable claims of the government whose title is to be determined."

In Versailles, however, "non-Western regions and peoples figure most often as inert masses of territory and humanity" (Manela, 2007a: x) during the negotiations, discussed 
doi: 10.14267/cojourn.2019v4n2a2

only in those rare cases when this served great power interests, and the participation of local actors was minimal even in these cases. The Covenant of the League of Nations had created the mandate system to ensure the development of the colonies of defeated powers in its Article 22, stating that "the well-being and development of such peoples form a sacred trust of civilisation and that securities for the performance of this trust should be embodied in this Covenant". Nevertheless, in the interwar era, this principle was implemented for the benefit of the colonial powers and against the self-determination of colonial people.

The great powers did not calculate with the incendiary effects of the principle of self-determination in the colonial world. However, WWI had not yet ended when they already had to face the phenomenon that colonial peoples began lobbying for their own nation-states, arguing that on the basis of ethnic consciousness they have a right to establish a sovereign state. Argumentations based on 'Wilsonian nationalism' emerged in Turkey, Egypt, Vietnam, India, China, Korea, Indonesia, Nigeria and in several other parts of Africa, among others (Steigerwald, 1999: 97; Manela 2007b). Similar claims were already disturbing enough in the case of Central Europe, where political borders did not coincide with nationalities. In the colonial world, the application of national selfdetermination was not only even more problematic to implement, it also clearly contradicted the interests of great powers, threatening the stability of their colonial rule.

Recognising this, Wilson himself entered into lengthy explanations, referring

"the unqualified hope that men have entertained everywhere of immediate emancipation from the things that have hampered them and oppressed them. You cannot in human experience rush into the light [of self-determination]. (...) You have to go through the twilight into the broadening day before the noon comes and the full sun is on the landscape" (Wilson, 1919b).

A more practical line of reasoning by him argued that "it was not within the privilege of the conference of peace to act upon the right of self-determination of any peoples except those which had been included in the territories of defeated empires." (Wilson, 1927: 244). These statements undoubtedly meant that the principle of national selfdetermination was initially not designed for colonies. Even if some of the imperial powers (the German, the Austro-Hungarian and the Ottoman empires), which were defeated in WWI, collapsed, the British and the French empires were actually strengthened as a 
doi: 10.14267/cojourn.2019v4n2a2

consequence of Versailles, leading to an unprecedented era of European colonial expansion (Manela, 2007b: 126).

Several scholars argue that Versailles and the surrounding debates are textbook illustrations of the inherently colonial and Eurocentric nature of IR since its very beginnings. Undeniably, in spite of Wilson's high-toned ideas about the equality of nations, Versailles reflected great power interests that were based on a "colonizer's model of the world" (Saurin, 2006: 27), and the decisions were made in an atmosphere of Western and European supremacy. There are manifold criticisms concerning the motivations and intentions of Wilson, accusing him of supporting American imperialism in the Western Hemisphere (Healy, 1988; Hall, 1995), emphasizing the principles of free trade and free navigation to foster the exploitation of the colonies (Steigerwald, 1999), or the controversial nature of the Wilsonian idea of interventions (Calhoun, 1986; Belloni, 2007), all imbued with traces of colonialism, Eurocentrism, and racism (Steigerwald, 1999).

Principles, however, can often enhance their discursive spaces and gain additional meanings in different contexts regardless of the motivations and intentions of their initiators. It was not otherwise in the case of national self-determination, either: in the colonial world, the resonance of the notion contributed to the development of the theoretical foundations of anti-colonial nationalist movements. On the other hand, the following disillusionment with Wilson's ideas fostered nationalist upheavals all over the colonized world, which made it clear that the peoples of the colonies strived for recognition in the new world order, and international society has begun its turn "from an imperial world order to a postcolonial one" (Manela 2007b: 123). The decline of colonial powers reached its peak several decades later. The principle of national self-determination and 'Wilsonian nationalism' not only contributed to bring about the events of WWII, but may thus (rather paradoxically) be named as an important turning point in the history of anticolonial movements, providing them with a comprehensive theoretical background to channel the manifold tensions and dissatisfaction stemming from the colonial world order. These movements, furthermore, have been used as case studies in the theoretical reflections of the postcolonial critiques of IR, further contributing to the development of IR as a discipline (see Manela, 2007b). 


\section{Conclusions}

There is no need to elaborate on the events of the 1920s-1930s in detail to prove the fact that the direct aims of the Treaty of Versailles were not fulfilled, let alone the excessive hopes of liberal internationalism about the instant creation of a more peaceful and just world on the blood-soaked ruins after WWI. The League of Nations itself is also often considered to be a failure, at least in reaching its declared practical objectives, while the principle of self-determination may be said to have only ignited tensions in both Europe and the colonial world in the interwar period and after. With a view to the development of IR, revisionist historians and IR theorists have also proven that the great narrative about the glorious 'overnight' birth of the discipline in 1919 is, in the strict sense, mostly a blend of the superficial reading of the historical events and the extrapolation of the discipline's contemporary state in the Cold War. However, if we consider the long-term impact of Versailles and the surrounding controversies, it is clearly visible that this era meant an unquestionably significant and formative time for the study of international relations and the establishment of IR as a discipline.

From the Liberal point of view, Versailles served as a forum where the foundations of the main principles and approaches of liberal internationalism were summarized and canonized, contributing to the development of the discipline of IR to further the quest of mankind for a more peaceful and just future. From the Realist point of view, it symbolises the time and the place where the 'strawman' image of the Idealist was born, against which Realist scholars were able to refine and develop their own ideas during the aftermath of WWII, in the time of the Cold War. The circumstances under which the Treaty of Versailles was discussed, signed and implemented, have also inspired the critiques of IR, especially in the form of anti- and postcolonial theories. The principles and approaches that the article has discussed above are typical subjects of extensive and often heated discourses within the discipline, which have emerged from the context of Versailles and the surrounding controversies, and keep influencing the development of IR since then. From this point of view, the most important achievement of Versailles deserving to be celebrated on the $100^{\text {th }}$ anniversary - lies in the creation of a wide discursive space in which the emergence of the principles of IR theory, defining principles for the course of the $20^{\text {th }}$ century, was made possible.

All things considered, the Treaty of Versailles was built upon a discourse about a set of ideas which, in the course of time, developed to define the central field of analysis of the discipline. In the meantime, the attempts at the practical implementation of the 
doi: $10.14267 /$ cojourn.2019v4n2a2

treaty during the 1920s-1930s provided IR with a range of instructive case studies to analyse and lessons to learn. In this sense, the conclusions support the claim of Anievas that "the theoretical significance of Versailles for IR can hardly be overstated" (Anievas, 2014: 619).

\section{References}

Anievas, A. (2014). International Relations between War and Revolution: Wilsonian Diplomacy and the Making of the Treaty of Versailles. International Politics, 51, pp. 619-647.

Ashworth, L. M. (2002). Did the Realist-Idealist Great Debate Really Happen? A Revisionist History of International Relations. International Relations, 16(1): pp. $33-51$.

Baranyi, T. (2019). Reassembling a World Order: Toward a New Historiography of the Paris Peace Conference. Corvinus Journal of International Affairs, 4(3), in this issue.

Baylis, J., Smith, S., and Owens, P. (2016). The Globalization of World Politics: An Introduction to International Relations. Oxford: Oxford University Press.

Belloni, R. (2007). Rethinking "Nation-Building:" The Contradictions of the NeoWilsonian Approach to Democracy Promotion. The Whitehead Journal of Diplomacy and International Relations, 8(1): 97-109.

Boemeke, M. E., Feldman, G. D., and Glaser, E. (1998). The Treaty of Versailles: A Reassessment After 75 Years. Washington DC and Cambridge: German Historical Institute and Cambridge University Press.

Buell, R. L. (1925). International Relations. New York: Henry Holt and Co.

Bull, H. (1995 [1977]). The Anarchical Society: A Study of Order in World Politics. London: Macmillan Press Ltd.

Calhoun, F. (1986). Power and Principle: Armed Intervention in Wilsonian Foreign Policy. Kent: Kent State University Press.

Carr, E. H. (1946 [1939]). The Twenty Years' Crisis 1919-1939: An Introduction to the Study of International Relations. London: Macmillan \& Co. Ltd.

Charter of the United Nations, 26 June 1945. Available at: https://www.un.org/en/charter-united-nations/ [Accessed 5 August 2019]. 
doi: $10.14267 /$ cojourn.2019v4n2a2

Davies, T. R. (2012). A "Great Experiment" of the League of Nations Era: International Nongovernmental Organizations, Global Governance, and Democracy Beyond the State. Global Governance, 18(4): pp. 405-423.

de Carvalho, B., Leira, H., and Hobson, J. M. (2011). The Big Bangs of IR: The Myths

That Your Teachers Still Tell You about 1648. Millennium: Journal of International Studies, 39(3), pp. 735-758.

Donnelly, J. (1995) Realism and the Academic Study of International Relations. In: J.

Farr, J. S. Dryzek, and S. T. Leonard, eds., Political Science in History. Cambridge: Cambridge University Press, pp. 175-197.

Drinkwater, D. (2005). Sir Harold Nicolson and International Relations: The Practitioner as Theorist. New York: Oxford University Press.

Fleury, A. (1998). The League of Nations: Toward a New Appreciation of Its History. In:

M. E. Boemeke, G. D. Feldman, and E. Glaser, eds., The Treaty of Versailles: A Reassessment After 75 Years. Washington DC and Cambridge: German Historical Institute and Cambridge University Press, pp. 507-522.

Goodrich, L. M. (1947). From League of Nations to United Nations. International Organization, 1(1): pp. 3-21.

Guilhot, N. (2008). The Realist Gambit: Postwar American Political Science and the Birth of IR Theory. International Political Sociology, 2(4): pp. 281-304.

Hall, L. B. (1995). Oil, Banks, and Politics: The United States and Postrevolutionary Mexico, 1917-1924. Austin, The University of Texas Press.

Healy, D. (1988). Drive to Hegemony: The United States in the Caribbean, 1898-1917. Madison: The University of Wisconsin Press.

Hobsbawm, E. J. (1992). Nations and Nationalisms since 1780: Programme, Myth, Reality. Cambridge: Cambridge University Press.

Holsti, K. J. (1998 [1991]). Peace and War: Armed Conflicts and International Order 1948-1989. Cambridge: Cambridge University Press.

International Covenant on Civil and Political Rights, 16 December 1966. Available at: https://www.ohchr.org/en/professionalinterest/pages/ccpr.aspx [Accessed 5 August 2019].

Jackson, R., Sørensen, G., and Møller, J. (2018): Introduction to International Relations: Theories and Approaches. Oxford: Oxford University Press.

Keylor, W. R. (1998). Versailles and International Diplomacy. In: M. E. Boemeke, G. D. Feldman, and E. Glaser, eds., The Treaty of Versailles: A Reassessment After 75 
doi: 10.14267/cojourn.2019v4n2a2

Years. Washington DC and Cambridge: German Historical Institute and Cambridge University Press, pp. 469-505.

Knock, T. J. (1995). To End All Wars: Woodrow Wilson and the Quest for a New World Order. Princeton: Princeton University Press.

Knock, T. J. (1998). Wilsonian Concepts and International Realities at the End of the War. In: M. E. Boemeke, G. D. Feldman, and E. Glaser, eds., The Treaty of Versailles: A Reassessment After 75 Years. Washington DC and Cambridge: German Historical Institute and Cambridge University Press, pp. 111-129.

Lynch, A. (2002). Woodrow Wilson and the Principle of 'National Self-Determination': A Reconsideration. Review of International Studies, 28(2): pp. 419-436.

Manela, E. (2007a). The Wilsonian Moment: Self-Determination and the International Origin of Anticolonial Nationalism. Oxford: Oxford University Press.

Manela, E. (2007b). Dawn of a New Era: The "Wilsonian Moment" in Colonial Contexts and the Transformation of World Order, 1917-1920. In: S. Conrad and D. Sachsenmaier, eds., Competing Visions of World Order: Global Moments and Movements, 1880s-1930s. New York: Palgrave Macmillan, 121-150.

Moon, P. T. (1925). Syllabus on International Relations. New York: The Macmillan Company.

Morgenthau, H. J. (1948). Politics Among Nations: The Struggle for Power and Peace. New York: A.A. Knopf.

Osiander, A. (1994). The States System of Europe, 1640-1990: Peacemaking and the Conditions of International Stability. Oxford, Clarendon Press.

President Woodrow Wilson's Fourteen Points, 8 January, 1918. Available at: https://avalon.law.yale.edu/20th_century/wilson14.asp [Accessed 5 August 2019].

Quirk, J., and Vigneswaran, D. (2005). The Construction of an Edifice: The Story of a First Great Debate. Review of International Studies, 31(1): pp. 89-107.

Saurin, J. (2006). International Relations as the Imperial Illusion; or, the Need to Decolonize IR. In: B. G. Jones, ed., Decolonizing International Relations, Lanham: Rowman \& Littlefield, 23-42.

Schmidt, B. (1998). The Political Discourse of Anarchy: A Disciplinary History of International Relations. State University of New York Press: Albany.

Schweller, R. L. (2001). The Problem of International Order Revisited: A Review Essay. International Security, 26(1), pp. 161-186. 
doi: 10.14267/cojourn.2019v4n2a2

Sharp, A. (2016). The New Diplomacy and the New Europe, 1916-1922. In: Nicholas Doumanis, ed., The Oxford Handbook of European History, 1914-1945. Oxford Handbooks Online, 1-22. Available at: https://www.oxfordhandbooks.com/view/10.1093/oxfordhb/9780199695669.001 $.0001 /$ oxfordhb-9780199695669 [Accessed 5 August 2019].

Smith, L. V. (2018). Sovereignty at the Paris Peace Conference of 1919. Oxford: Oxford University Press.

Smith, S., Hadfield, A., and Dunne, T. (2016): Foreign Policy: Theories, Actors, Cases. Oxford: Oxford University Press.

Steans, J., Pettiford, L., Diez, T., and El-Anis, I. (2010). An Introduction to International Relations Theory:Perspectives and Themes. London: Pearson Education Limited.

Steigerwald, D. (1999). Historiography: The Reclamation Of Woodrow Wilson? Diplomatic History, 23(1): pp. 79-99.

The Covenant of the League of Nations, 28 June 1919. Available at: https://avalon.law.yale.edu/20th_century/leagcov.asp [Accessed 5 August 2019].

Treaty of Peace with Germany (Treaty of Versailles), 28 June 1919. Available at: https://www.loc.gov/law/help/us-treaties/bevans/m-ust000002-0043.pdf [Accessed 5 August 2019].

Vitalis, R. (2005). Birth of a Discipline. In: D. Long and B. C. Schmidt, eds., Imperialism and Internationalism in the Discipline of International Relations. State University of New York Press: Albany, pp. 159-182.

Weisbrode, K. (2014). Old Diplomacy Revisited: A Study in the Modern History of Diplomatic Transformations. New York: Palgrave Macmillan.

Wilson, W. (1918). President Wilson's Address to Congress, Analyzing German and Austrian Peace Utterances. Delivered in Joint Session, February 11, 1918. Available at: https://wwi.lib.byu.edu/index.php/President_Wilson\%27s_Address_to_Congress ,_Analyzing_German_and_Austrian_Peace_Utterances [Accessed 5 August 2019].

Wilson, W. (1919a). Address from Rear Platform, Richmond, Ind., September 4, 1919. Available at: https://archive.org/stream/addressesofpresi00wilsuoft/addressesofpresi00wilsuof t_djvu.txt [Accessed 5 August 2019]. 
Wilson, W. (1919b). After-Dinner Remarks, Paris, May 9, 1919. In: A. S. Link, ed., The Papers of Woodrow Wilson. Princeton: Princeton University Press, 58: 598.

Wilson, W. (1927). The Public Papers of Woodrow Wilson: War and Peace. New York: Harper \& Brothers. 